\title{
US plans for science outreach to Muslim world
}

\author{
The administration of US President \\ Barack Obama is ramping up \\ plans to develop scientific and \\ technological partnerships with \\ Muslim-majority countries. \\ The move follows a June speech \\ by Obama at Cairo University \\ in Egypt, when he promised \\ to appoint regional science \\ envoys, launch a fund to support \\ technological development \\ and open centres of scientific \\ excellence in Africa, the Middle \\ East and southeast Asia. So far, the \\ science-envoy plan is closest to \\ getting off the ground, say White \\ House officials, who see it as part \\ of a broader drive to improve \\ relations with the Islamic world. \\ "Polling consistently shows that \\ science and technology is an area
}

\author{
where the United States is widely \\ respected for its leadership," says a \\ top administration official, speaking \\ on condition of anonymity. "This \\ is a key part of the comprehensive \\ partnerships we are pursuing with \\ Muslim-majority communities." \\ The effort is being led by the \\ National Security Council and the \\ Office of Science and Technology \\ Policy. \\ The White House plans for \\ leading US scientists to visit \\ a Muslim-majority region for \\ several weeks, to canvass local \\ researchers, community leaders \\ and others for ideas that would \\ shape scientific initiatives. \\ Various US embassies have \\ already identified themes of \\ interest, officials say. Lebanon, for
}

discuss science and technology exchanges. Syrian researchers told it that their greatest need was for more training for nurses and medical technicians. Setting up a training centre along those lines might be "low-hanging fruit" for the White envoy is expected to be announced "shortly", according "This is a key House to pluck off,
to the administration official.

"They [the administration] clearly have the door open for ideas, and part of the partnerships with the White House will parthers White House will Muslim-majority need to work withi communities." $\quad$ or around science we have ideas," says John Boright, already underway, such as the director of international affairs at Masdar eco-city in the United the National Academy of Sciences Arab Emirates and the King in Washington DC, an independent Abdullah University of Science advisory group.

Boright was part of a delegation that visited Syria this spring to and Technology, due to open next month in Saudi Arabia.

Alexandra Witze

\section{Fossil protection law comes under fire}

Chinese palaeontologists met government officials in Beijing last week to lobby for strict federal control of fossil specimens. The researchers are working to get changes incorporated into a draft law released in March by the Legislative Office of the State Council, which advises China's leaders, and the Ministry of Land and Resources.

As China has experimented with private enterprise, poor farmers have burrowed into hillsides, uncovering fossils from the Cretaceous to the Jurassic that have rewritten the palaeontological literature. With international traders paying tens of thousands of dollars for important finds, provincial officials have fought with the federal government for control over permits to dig and regulate the bounty.

Yet many scientists inside and outside China fear that the proposed federal law may foster the rampant trade in illegal fossil specimens. Zhou Zhonghe, director of the Institute of Vertebrate Paleontology and Paleoanthropology in Beijing, and other researchers have proposed several changes. These would include giving the land and resources ministry authority over vertebrate

fossil collections, and setting up a national panel of palaeontologists to regulate the collections on a nationwide level. "I think many of our suggestions will be adopted," Zhou says.

The law isn't expected to be finalized until early next year. The process is being watched closely by researchers worldwide who collaborate with Chinese palaeontologists. "I am in complete support of the Chinese government and academic institutions trying to clarify the laws to protect their tremendous fossil

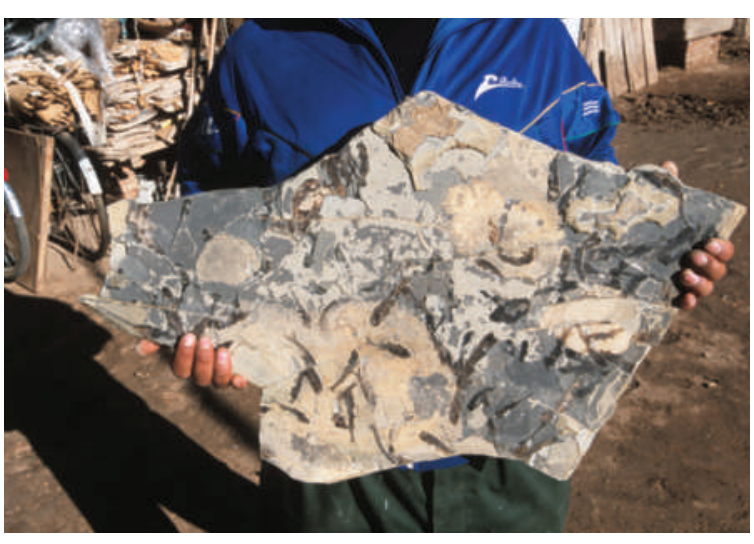

Fossils found in Chinese rock formations have fuelled a cottage industry in illegal trading of specimens. heritage," says palaeontologist Mark Norell of the American Museum of Natural History in New York.

Palaeontologist Gao Keqin, of Peking University, remains deeply concerned. He says that recent versions of the draft law would not prevent provincial officials from blocking research by demanding large sums from scientists.

"The current situation is problematic because local jurisdictions with rightful interests but only a vague understanding of the scientific value of fossils can unilaterally stop legitimate scientific exploration," says James Clark, a palaeontologist at George Washington University in Washington DC.

Many provinces built palaeontological museums in the hope of tapping the tourist trade, but fossil smugglers often use them as a front to buy and sell specimens. "Fossils require an institution with staff educated in curation and preservation," says Clark. "But few places in China have these facilities."

"I hope the new law will let us protect the fossil heritage," says Zhou. Rex Dalton 